\title{
A hegyek rituális szerepe a Shang-korban ${ }^{1}$
}

A Shang-dinasztiával 商 kapcsolatban (i. e. 16. sz. közepe - i. e. 1045) közvetlen források elsősorban a második főváros időszakából (kb.i.e. 1300-tól) állnak rendelkezésünkre.A Shang-korról alapvetôen a rituális bronzedények, illetve az 1899-tôl kezdve különböző ásatások során felfedezett jóslócsontok tudósítanak. Mindkét lelettípus domináns módon egyetlen térséghez köthető, a mai Henan tartomány északi részén található Anyang 安阳 városától három kilométerre fekvő Xiaotun 小屯 településhez, amely az utolsó 12 Shang uralkodó szakrális-adminisztratív központja volt. Az itt rendkívül intenzíven gyakorolt marhalapocka-jóslás (szkapulomanteia), illetve teknősbékapáncél-jóslás (plasztromanteia) során felhasznált jóslócsontok feliratai elsősorban a korszak vallási keresztmetszetét mutatják. A kínai írás és nyelv e legkorábbi emlékei alapján állíthatjuk, hogy a Shang-kori jósok az uralkodót érintő minden kisebb és nagyobb kérdésben megkérdezték a szellemek világát, amelynek világosan strukturált rendje volt: a hierarchia tetején a mindent uraló Divel 帝, neki közvetlenül alárendelve pedig a különböző természeti erők és a különféle típusú ôsök szellemei helyezkedtek el.

\section{A Shang-kori pantheon}

Míg a királyi ôsöknek a tíznapos Shang „hét” (xun 旬) struktúrájában rendszeresen mutattak be áldozatot, addig logikusnak tûnhet, hogy a természeti erőknek szóló áldozatok elsősorban az aktuális körülményektől függtek. A Shang-korban már használták a (későbbi elnevezéssel) 10 égi törzsnek

1 A tanulmány az OTKA 100632 számú pályázatának keretében készültt. 
(shi tiangan 十天干) és 12 földi ágnak (shi'er dizhi 十二地支) nevezett két lista kombinációjával kialakított 60 napos naptárrendszert. ${ }^{2}$

A Shangok által tisztelt természeti erók közé tartozott a Föld ( $t u$ 土, később a földoltár), a Sárga-folyó (He 河), a nap ( $r i$ 日) és a felhők (yun 云) szelleme, illetve a jelen tanulmány tárgyát képezó hegy vagy hegyek. Közülük különösen a Sárga-folyó és a hegyek játszottak kitüntetett szerepet, mivel ezek voltak felelősek az esőzésért, amely kiemelt fontosságú volt a mezőgazdaság köré szerveződő társadalomban.

A következőkben tehát a Shang-kor második feléből származó jóslócsontok alapján a korabeli vallási panteon természeti erői közül a hegyre koncentrálok. A kutatásban egyértelmúnek szokás venni, hogy a különböző természeti jelenségek általában megszemélyesített szellemi lények, így ennek alapján a jóslócsontokon hegyként megjelenő szót gyakran fordítják „Mountain Power”-nek. ${ }^{3}$ Az adott természeti jelenségnek (hegy, folyó, felhő stb.) a mintegy mögötte álló szellemi erőhöz fúződő pontos viszonya ugyanakkor magukból a jóslócsontokból aligha derül ki, mivel azokon alapvetôen kizárólag a hegy(csúcs), folyó vagy felhő szavak állnak. Nagyon ritkán találkozunk ennél részletesebb megnevezéssel, bár ilyenek is léteznek, például a hegy(csúcs)-ős (yuezong 岳宗) szókapcsolat, amely a Hegy tiszteleti megnevezése lehetett. ${ }^{4}$

A következőkben összegyújtött egyes feliratokat megpróbálom magyarul pontosan visszaadni, és magukat a fordításokat nem egészítem ki további értelmezésekkel. A Shang-kori írásjegyek speciális jellege miatt a kínai szövegekben a nekik megfeleló, általánosan elfogadott klasszikus írásjegyet használom, ha pedig ez nem lehetséges, akkor azt a lábjegyzetben jelzem.

Kósa 2012.

Lásd például Keightley (2014) tanulmányait.

Heji 30298, Lian 2011: 12. 


\section{Hegyekkel kapcsolatos jóslócsont-feliratok}

Habár a Shang-kori vallásosságnak - fontosságban az ősök kultusza után következve - közismerten jelentős részét alkotják a természeti erókkel kapcsolatos vallási megnyilvánulások, ennek ellenére az utóbbiakról az elmúlt mintegy száz évben viszonylag keveset írtak. A Shang-kori jóslócsontokkal kapcsolatos tanulmányok többsége az írásjegyek valóban számos nehézséget rejtó azonosítására koncentrált, míg a tartalmi elemzések elsősorban a Shang-kori uralkodók, illetve a nekik bemutatott áldozatok jellegét igyekeztek feltárni, így a természeti jelenségekre, és ezen belül a hegyekre vonatkozó feliratok jóval kisebb figyelmet kaptak. Összefoglaló munkájukban David N. Keightley vagy Robert Eno természetesen tárgyalja a kérdést, de Lian Shaoming 连劭名 2011-es, kínaiul mindössze négy és fél oldalas, a hegy- és a folyókultuszról egyaránt szóló írásában például a témáról szóló egyetlen korábbi kínai tanulmányra sem tud hivatkozni.

Elsőként érdemes azzal foglalkozni, hogy a hegykultusz vizsgálata során egyáltalán milyen írásjegyet keresünk. Sajnálatos módon már itt akadályba ütközünk. A jóslócsontokon leggyakrabban szereplő, rituális összefüggésben említett hegy szó a yue 岳 (más alakban: 获), amely magas hegyet, illetve ennek a csúcsát jelenti. Ezzel az írásjeggyel kapcsolatban két alapvetô kérdés merül fel. Egyrészt a kutatásnak nincs teljesen egyöntetú véleménye, hogy a jóslócsontokon szereplő írásjegy ( 笜) valóban megfeleltethetô-e a későbbi 岳 írásjegynek: Qu Wanli 屈萬里 1960-as tanulmánya szerint igen, ${ }^{5}$ David N. Keightley, a Shang-kor egyik legkiemelkedőbb szakértője viszont egy másik kínai írásjegyet olvas annak helyén, amikor a mások által yueként 岳 átírt hegycsúcsot egy yang vagy xiang kiejtéssel rendelkező, alul 山, középen felette pedig egy 羊 elemből álló írásjegyként azonosítja (姜). ${ }^{6}$

Másodikként az a kérdés merül fel, hogy mire utal ez az írásjegy, egy vagy több hegyre, illetve konkrétan melyik(ek)re. Hozzá kell tenni, hogy ez utóbbi

Idézi Kleeman 1994: 226, n. 2.

6 Például Keightley 2000: 104, 2014: 157. 1982-ben D. N. Keightley (1982: 268-269, n. 5, illetve p. 281) még elvetette az eredetileg Akatsuka Kiyoshi 赤塚忠 által felvetett írásjegy-ötletet. A japán kutató olvasatot eredetileg nem rendelt az írásjegyhez. 
kérdésben viszonylagos konszenzus uralkodik (pl. Sun Yirang 孫詒讓, Sarah Allan), hogy „a Hegy(csúcs)” nem más, mint a későbbiekben Songnak nevezett hegy (Songshan 嵩山), ${ }^{7}$ de van olyan kutató, aki a Huo-heggyel (Huoshan 霍山, Huotai shan 霍太山, Taiyue shan 太岳山) azonosítja, ${ }^{8}$ illetve olyan is, aki például egy sokkal általánosabb hegy-koncepciót feltételez az írásjegy mögött.?

A többi természeti jelenséghez hasonlóan a Hegy vagy Hegycsúcs is kizárólag rituális összefüggésben fordul elő, így egyrészt vele kapcsolatos különböző szertartásokról, másrészt e szertartások következményeiről olvashatunk, a következőkben tehát e rituális cselekedetekre, illetve ezek következményeire koncentrálva mutatom be a Hegycsúccsal kapcsolatos elképzeléseket. Az egyes jóslócsontokra történő hivatkozásnál a kínai verzió után megadom a standard gyújtemények típusát (pl. Heji 合集, Tunnan 屯南, Cuibian 粹編) és az azokban található felirat sorszámát. ${ }^{10} \mathrm{~A}$ lenti szövegek két szakkifejezést használnak: az első a jóslás szertartására ( $b u$ 下) vonatkozik, amikor egy felhevített bronzrudacskát nyomtak a teknősbékapáncélba vagy a marhalapockacsontba, amelyen ezek után repedések keletkeztek, a második (zhen 貞) az ezen repedések értelmezése során keresett jóskérdésre vonatkozik.

\subsection{A szertartások típusai}

A ránk maradt jóslócsontok számos fontosabb szertartást említenek a Heggyel kapcsolatban: 1. égóáldozat (liao 燎); 2. you-vágóáldozat (酊); 3. Hegyhez vonulás (qu yue 取岳, zou yue 奏岳); 4. Egyéb rítusok. A következőkben röviden ezeket vizsgálom egyenként. D. N. Keightley megfigyelése szerint a dinasztia vége felé nem gyakorolták vagy legalábbis nem jegyezték fel a természeti erőknek (például a Hegynek) szóló szertartásokat, ${ }^{11}$ így a következókben vizsgálandó feliratok nagyjából az i. e. 1300-1100 közötti időszakról tudósítanak.

Itō 1996: 63, Keightley 2000: 104, n. 21, Kleeman 1994: 227.

Qu Wanli véleményét idézi Kleeman 1994: 227.

Akatsuka Kiyoshi véleményét idézi Keightley 1982: 295.

10 A jóslócsontok feliratairól, illetve az ezeket tartalmazó gyújteményekról lásd Wilkinson 2013: 684-687, Keightley 1990, Keightley 1997.

11 Keightley 1978: 177. 


\subsection{1. Égóáldozat}

Az égóáldozat (liao 燎) részleteirôl meglehetôsen keveset tudunk, bemutatásának pontos leírása nem maradt ránk, csak magából a szóból feltételezhetjük, hogy a lényege az állatok olyan szintú elégetése volt, amely után már nem voltak alkalmasak fogyasztásra, illetve sokak szerint elképzelhetô, hogy az állatokat élve helyezték a túzre. ${ }^{12}$ A szertartástípus legjellegzetesebb alkalmazási területei a természeti eróknek szóló áldozatok voltak, és csak nagyon ritkán fordult elő, hogy a királyi ősök részesültek volna benne. ${ }^{13}$

„Jiyou napon jóslás történt: xinhai napon mutassunk be égőáldozatot a Hegynek esőért. Jiyou napon jóslás történt: xinhai napon égőáldozatként mutassunk be esőért a Hegynek egy különleges szarvasmarhát, és nyissunk fel egy (átlagos) szarvasmarhát." 己西, 貞辛亥其燎于岳雨。已西, 貞辛亥其燎于 岳一牢, 卯一牛, 雨。[Heji 34197]

A Shang-kori jóslócsontokon található mondatok még nem rendelkeznek a Keleti Zhou-kori nyelvtan komplexitásával, így értelmezésük időnként kevésbé egyértelmú. Jelen esetben az áldozatbemutatás cselekvése ('égóáldozatot bemutatni', liao 燎) után yuvel 于 bevezetve következik az, akinek az áldozatot bemutatják ('Hegy', yue 岳), majd sorrendben utána az áldozat tárgya ('egy különleges szarvasmarha', yi lao 一牢), és a legvégén áll az áldozat célja ('eső', yu 雨).

A Shang udvar külön tenyésztette a szarvasmarhák különböző típusait, hogy azután feláldozzák őket. Már itt találkozunk egy az állatok értékét érintő megkülönböztetéssel: míg a niu 牛 átlagos szarvasmarhát jelöl, addig a lao 牢 egy különlegesen tenyésztett szarvasmarha-féleségre utal, amelyiket meghatározott ideig bekerített területen neveltek. ${ }^{14}$ Mint ez a következő idézetekből kiderül, az égólldozatok leggyakoribb tárgyai ezek a szarvasmarhák, és csak ritkán találkozunk egyéb állattal (pl. kutyával a legutolsó példában):

\footnotetext{
Itō 1996: 72

13 Itō 1996: 70, 141.

14 Li 2007: 27-28. Hu Houxuan 胡厚宣 1939-es tanulmányában azt vetette fel, hogy a lao 牢 egy hím és egy nőstény állatpárt jelentett (Li 2007: 27, n. 34).
} 
„Jóslásszertartás jiachen napon: Yisi napon mutassunk be égóáldozatként a Hegynek (egy) nagy, különleges szarvasmarhát könnyú esóért?”甲辰卜，乙巳其燎于岳，大牢，小雨。 [Heji 33331]

„Jóslásszertartás xinwei napon, Zheng jóslása: a következő guiyou napon hívják Qiaót, ${ }^{15}$ hogy mutassa be az égóáldozatot a Hegynek.”辛未卜, 争貞犲癸西乎雀燎于岳。[Heji 4112]

„Égóáldozatot mutatunk be a Hegynek, este birkákat, a rákövetkező xinhai napon pedig boráldozatot és különleges szarvasmarhákat.”燎于岳, 夕羊, 犲辛亥酒牢。[Yingguo 114]

„Jóslásszertartás guiyou napon, a jóslás: égóáldozatként három kisebb, különleges szarvasmarhát mutatunk be a Hegynek, három különleges szarvasmarhát nyitunk fel. Jóslásszertartás bingzi napon, a jóslás: you-vágóáldozat keretében áldozzunk három kisebb, különleges szarvasmarhát a Hegynek, három különleges szarvasmarhát nyissunk fel. Jóslás: három kisebb, különleges szarvasmarhát (áldozzunk), három szarvasmarhát nyissunk fel.” 癸西卜, 貞燎于岳三小牢, 卯三牢。丙子卜, 貞酒岳三小 牢, 卯三牢。貞三小牢, 卯三牛。[Heji 14430]

„Jóslásszertartás guiyou napon, Bin jóslása: égőáldozatként két kisebb, különleges szarvasmarhát mutassunk be a Hegynek, két különleges szarvasmarhát nyissunk fel. Jóslás: égóáldozatként három kisebb, különleges szarvasmarhát mutassunk be a Hegynek, két különleges szarvasmarhát nyissunk fel.” 甲午卜, 賓 貞燎于岳二小牢, 卯二牢。貞燎于岳三小牢, 卯二牢。 [Heji 9560]

15 A mondatot a következő jóslat analógiájára értelmeztem: „Jóslásszertartás yichou napon, Zheng jóslata: ismét hívjátok Qiaót, hogy egy kutyát mutasson be égőáldozatul a Felhőnek. 已 丑卜、爭貞、亦呼雀燎于云犬。(Itō 1996: 21). 
„A mai napon égőáldozatként áldozzunk kutyát a Hegynek. Wushen napon tíz kutyát.”今日燎于岳犬。戊申, 十犬。 [Heji 14452]

„Dingwei napon jóslás: (jó) termést kérünk a Hegytől, égőáldozatként három kisebb különleges szarvasmarhát ajánlunk fel, és három szarvasmarhát vágunk fel.”丁未, 貞 : 求禾于岳, 燎 三小牢，卯三牛。[Heji 33292]

Az egyszerúbb típusú áldozati szarvasmarhák (niu 牛) mennyisége (egy, illetve három) kevésnek túnik, más jóslócsontokon nem ritkán (bár nem is kizárólagosan) szerepel 50, 100, 300, 500, sôt 1000 állat is. ${ }^{16}$ Ugyanakkor a különlegesebb fajtából (lao 牢) más feliratok szerint is viszonylag keveset (egyet, hármat, tizenötöt) áldoztak. ${ }^{17}$

\subsubsection{Vágóáldozat}

Az ún. you-vágóáldozatot (酸) jelölő Shang-kori írásjegyet gyakran értelmezik valamilyen alkoholos italáldozatnak (jiu 酒, a kínai részben ezt az írásjegyet szerepeltetem), de Takashima Ken-ichi 高嶋謙一 meggyőzően érvelt amellett, hogy ez egy különleges vágóáldozat lehetett, amelynek semmilyen kapcsolata nincs az italáldozattal, így a következőkben a japán kutató értelmezését követem, ${ }^{18}$ és a lenti példák is arra utalnak, hogy nem italáldozatról van szó.

„Jóslás: xinwei napon végezzünk you-vágóáldozatot a Hegynek.”貞...幸未酒岳。[Heji 8843]

„... a Hegynek a következő xinyou napon mutassunk be you-vágóáldozatot.”.....岳于来辛西酒。[Tunnan 4032]

\footnotetext{
16 A konkrét szövegeket hivatkozással lásd Li 2007: 28-29.

17 A konkrét szövegeket hivatkozással lásd Li 2007: 28-29.

18 Takashima 2000: 389-390, Takashima 2002: 118-110.
} 
„Égóáldozatot mutatunk be a Hegynek, este birkákat, a rákövetkező xinhai napon pedig you-vágóáldozatot különleges szarvasmarhákkal.” 燎于岳, 夕羊, 犲辛亥酒牢。[Yingguo 114]

„Jóslásszertartás guihai napon, jóslása: a rákövetkező xinwei napon you-vágóáldozat keretében áldozzunk három kisebb, különleges szarvasmarhát a Hegynek, három ... nyissunk fel.” 癸 亥卜, 貞犲辛未酒岳三小牢, 卯三......。 [Heji 14471]

„(Jóslásszertartás) dinghai napon. A jóslat: xinmao napon mutassunk be you-vágóáldozatot a Hegynek, és égóáldozatként mutassunk be három különleges szarvasmarhát, és daraboljunk fel egy különleges szarvasmarhát.” 丁亥, 貞辛卯酒岳, 燎三 牢, 组牢。[Tunnan 1118]

„Jóslásszertartás wuwu napon, Bin jóslása: a jó aratásért mutassunk be you-vágóáldozatot a Hegynek, a Folyónak és Kuinak.”19 戊午卜, 賓貞 : 酒求年于岳、河、蒈。 [Heji 10076]

\subsubsection{A hegyhez vonulás szertartása}

A jóslócsontok viszonylag gyakran említenek egy szertartást, amelyet zou yue 奏 岳 vagy qu yue 取岳 névvel illetnek. Lian Shaoming szerint a hegyet megelőző szó mindkét esetben egy 'kivonulni, kimenni' jelentésú igének felel meg ( $q u$ 取 = $q u$ 趣, illetve $z o u$ 奏 $=z o u$ 走). Mindehhez érvként Lian az i. sz. 200 körülról (tehát a jóslócsontok után kb. 1400 évvel késóbbről) származó Shiming 釋名 példáját említi, amely mú valóban utal ezen írásjegyek azonosságára (pl. 取, 趣也). ${ }^{20}$ A részletek ismere nélkül itt is csak általánosan állíthatjuk, hogy valószínúleg a hegyhez történő rituális kivonulásról lehet szó, amely a kifejezés kontextusából úgy túnik, hogy majdnem mindegyik esetben az eső előidézésével függ össze.

\footnotetext{
19 Eno 2009: 63.

20 Lian 2011: 13.
} 
Elsőként következzék tehát néhány példa az első kifejezésre (qu yue), amelyról már itt érdemes megjegyezni, hogy sokan Lian Shaomingtól eltérően ezt nem egy kivonulási rítussal azonosítják, hanem egy qunek nevezett speciális esőkéró szertartással ${ }^{21}$ így a lenti mondatokban mindkét fordítást megadom.

„Jóslásszertartás yimao napon, Bin jóslása: vonuljunk a Hegyhez / mutassuk be a Hegynek a $q u$-szertartást.”已卯卜, 賓貞取岳。 [Heji 5522]

„Jóslásszertartás guiyou napon: vonuljunk a Hegyhez (áldozatra) / mutassuk be a Hegynek a $q u$-szertartást esőért.” 癸西卜, 其取岳, 雨。[Heji 34124]

„Jóslásszertartás guiyou napon: vonuljunk a Hegyhez / mutassuk be a Hegynek a $q u$-szertartást, hogy essen az eső?”22 癸西 卜, 其取岳, 雨? [Cuibian 28]

„Jóslásszertartás renyin napon, jóslat: ajánljunk fel gabonát a Hegynek, égóáldozatul ajánljunk fel három kisebb, különleges szarvasmarhát. Renyin napon vonuljuk a Hegyhez / mutassuk be a Hegynek a $q u$-szertartást esóért." 壬寅, 貞其拜禾于岳, 燎三小牢，壬寅·貞其取岳，雨。[Tunnan 3083]

„Jóslásszertartás xinyou napon: vonuljunk a Hegyhez / mutassuk be a Hegynek a qu-szertartást esőért. Jóslásszertartás dingwei napon: mutassunk be you-áldozatot ${ }^{23}$ a Hegynek, ajánljunk fel gabonát. Jóslásszertartás dingwei napon: estig esni fog. Jóslásszertartás gengwu napon: mutassunk be you-áldozatot a Hegynek, ajánljunk fel gabonát." 辛西卜, 取岳雨。雨。丁未卜, 又于岳, 拜 禾。丁未卜, 及夕雨。庚戍卜, 又寸岳, 拜禾。[Heji 34217]

21 Hu Houxuan 1994-es tanulmányára utalva Itō 1996: 14.

22 Serruys 1974: 54-55.

23 A you 又 írásjegynek rendkívül sok jelentése van a jóslócsontok szövegében, közülük az egyik egy speciális áldozattípus (Takashima 1996: 303). 
Egy másik kifejezés (zou yue 奏岳) viszonylag ritkábban fordul elő a feliratokon. Az utolsó két példában, ahol a két töredék (Tunnan 4513 + 4518) eredetileg egy csonthoz tartozott, mintha három szinonim kifejezést (qu yue 取岳, zou yue 奏岳, ru yue 入岳) találnánk.

„Jóslás: Menjünk a Hegyhez.” 貞奏岳。 [Heji 14475]

„Jóslás: Ne menjünk a Hegyhez.”貞勿奏岳。 [Yingguo 1153]

„Jóslásszertartás xinsi napon: vonuljunk-e a Hegyhez / mutassuk be a Hegynek a qu-szertartást? Kövessük? Ne kövessük? Jóslásszertartás yiyou napon: (valamelyik) bing napon menjünk-e a Hegyhez?" 辛巳卜, 取岳, 從。不從。乙西卜, 于 丙奏岳。[Tunnan 4513]

„Jóslásszertartás bingshen napon: menjünk Hegyhez.” 丙申 卜, 入岳。[Tunnan 4518]

Miközben a fenti kifejezések mintha az adott szertartás terminus technicusai lennének, eközben bizonyos esetekben egyszerúen a kivonulást jelölő wang 往 írásjegy vagy a küldést, illetve megbízást kifejező shi 使 írásjegy szerepel, melyek egyértelmúsíteni látszanak, hogy valóban egy konkrét rituális kivonulásról van szó.

„Menjünk ki a Hegyhez, hogy feláldozzunk három nagy, különleges szarvasmarhát?”其往于岳，惠三大牢。[Heji 30422]

„Mutassunk be égóáldozatot a Hegynek, küldjünk valakit a Hegyhez? Az odamenetele jóváhagyva. Jóslás: bízzunk meg valakit, hogy vonuljon a Hegyhez. Az odamenetele jóváhagyva." 燎 于岳，使人于岳。入若。貞使人于岳。入若。[Heji 5518] 
„Jóslás: ne küldjünk embert a Hegyhez? Küldjünk embert a Hegyhez? Jóslat: küldjünk embert a Hegyhez.” 貞勿使人于 岳。使人于岳。貞使人于岳。[Heji 5520]

„Jóslás: küldjünk valakit a Hegyhez. Jóslás: ne küldjünk valakit a Hegyhez. Jóslás: a király ne menjen oda.”24 貞使人于岳。 貞勿使人于岳。貞王勿入。[Heji 5521]

Az utolsó három példa láthatólag arra utal, hogy a királyi udvar megbíz valakit, hogy vonuljon ki a Hegyhez, és a második esetben ott mutasson be áldozatot. A legutolsó idézet arra látszik utalni, hogy a király talán néha az illetővel ment, de itt konkrétan nincs erre szükség.

\subsubsection{Egyéb szertartások}

Az égőáldozat, a you-vágóáldozat, illetve a Hegyhez történő kivonulás a leggyakrabban említett szertartások, ugyanakkor néhány jóslócsont arról tanúskodik, hogy léteztek a Hegynek bemutatott egyéb rítusok is.

„Jóslás gengxu napon: A király saját maga imádkozzon a Hegyhez." ${ }^{25}$ 庚戌卜: 叀 ${ }^{26}$ 王自禱于岳。 [Heji 82801]

„Ha a Hegyet kérleljük a jó aratásért, lesz ebből eső?” 于岳求 年, 此雨。[Nanming 424]

„Ha a Hegyet kérleljük a jó aratásért, ebből nagy eső lesz.” 求 年于岳, 兹有大雨。[Nanming 426]

„... végezzük el a si-rítust a Hegynél.” ${ }^{27} \ldots$ 祀 (処) 在山。

[Heji 19622]

Keightley 2000: 114.

25 Keightley 2000: 65.

26 Az írásjegy jelentéséről lásd Keightley 1982: 305, ettől eltérô véleményról lásd Serruys 1974: 115-119.

27 A si-rítusról lásd Takashima 2009. 
„Ha táncot mutatunk be a Hegynek, lesz eső.”28 舞岳又(= 有)

雨。[Heji 14207]

„Mutassunk be táncot a Hegynek? Ne mutassunk be táncot a Hegynek?”舞岳。勿舞岳。[Heji 12842]

\subsection{A szertartások körülményei és célja}

Mivel a Shang-kori jóslócsontok a jóslás napja mellett általában pontosan számon tartották az elvégzendő szertartás időpontját is, így ezzel kapcsolatban is rendelkezünk bizonyos információkkal. Mint látni fogjuk, a helyszínre vonatkozóan ugyanakkor alig találunk utalást. Ezen kívül a fent már bemutatott feliratok, illetve néhány egyéb felirat megvilágítja az áldozatok elsődleges céljait.

2.2.1. Az áldozás idôpontja és helyszíne

Ami az áldozások időpontját illeti, Lian Shaomingnek talán igaza van abban, hogy azokra általában a tíz égi törzs xin 辛 napján került sor, ${ }^{29}$ így a jóslócsontokon megadott dátumok első tagjaként általában ez jelenik meg.

„Jóslás: xinwei napon áldozzunk bort a Hegynek.”貞......辛未 酒岳。[Heji 8843]

„Jóslásszertartás guihai napon, jóslás: a rákövetkező xinwei napon you-vágóáldozat keretében áldozzunk három kisebb, különleges szarvasmarhát a Hegynek, három ... nyissunk fel.” 癸 亥卜, 貞犲辛未酒岳三小牢, 卯三...... [ Heji 14471]

„Jóslásszertartás bingchen napon, a mostani xinyou napon you-áldozatot mutatunk be a Hegynek.” 丙辰卜, 今辛西又于 岳, 用。[Tunnan 2305]

28 Serruys 1974: 28.

29 Lian 2011: 14. 
a Hegynél xinchou napon szerencsés you-vágóáldozatot mutatunk be, nagy eső lesz.” .....岳辛丑其福酒，又大雨。 [Tunnan 622]

„(Jóslásszertartás) dinghai napon. A jóslás: xinmao napon mutassunk be you-vágóáldozatot a Hegynek, és égóáldozatként mutassunk be három különleges szarvasmarhát, és daraboljunk fel egy különleges szarvasmarhát." 丁亥, 貞辛卯酒岳, 燎三 牢，组牢。[Tunnan 1118]

„... a Hegynek a következő xinyou napon mutassunk be you-vágóáldozatot.”.....岳于来辛西酒。[Tunnan 4032]

„Jiyou napon jóslás történt: xinhai napon mutassunk be égóáldozatot a Hegynek esőért. Jiyou napon jóslás történt: xinhai napon égőáldozatként mutassunk be esőért a Hegynek egy különleges szarvasmarhát, és nyissunk fel egy (átlagos) szarvasmarhát." 已西, 貞辛亥其燎于岳雨。已西, 貞辛亥其燎于 岳一牢, 卯一牛, 雨。[Heji 34197]

A fenti szabály ugyanakkor mégsem univerzális, hiszen, bár jóval ritkábban ugyan, de más napokról (jia 甲, yi 乙,ji 己,gui 癸) is szó esik néhány feliraton.

„Jóslásszertartás jiachen napon: Yisi napon mutassunk be égóáldozatként a Hegynek egy nagy, különleges szarvasmarhát könnyű esőért?”甲辰卜，乙巳其燎于岳，大牢，小雨。[Heji 33331]

„Ji napon égőáldozatként disznót áldozunk a Hegynek esőért. Xin napon égőáldozatot mutatunk be esőért.”惠已燎豕与岳 雨。于辛燎雨。[Heji 34209]

„Jóslásszertartás xinwei napon, Zheng jóslata: a következő guiyou napon hívják Qiaót, hogy mutassa be az égóáldozatot a Hegynek.”辛未卜，争貞犲癸西乎雀燎于岳。[Heji 4112] 
Ami az áldozati rítusok helyszínét illeti, első megközelítésben a leglogikusabb nyilvánvalóan az lenne, ha a Hegynek bemutatott áldozatokat magánál a Hegynél mutatták volna be. Ugyanakkor éppen a korábban említett példák valószínúsítik, hogy ez lehetett a ritkább eset. A harmadikként (2.1.3.) említett „kivonulás a Hegyhez” szertartás arra látszik utalni, hogy a feliratokon külön jelezték, ha kivonulásról volt szó, mivel annak is meglehetett a sajátos koreográfiája, így feltételezhetjük, hogy amikor nem említik a kivonulást (és ilyen a legtöbb eset), akkor ez nem is történt meg, tehát az adott szertartást, például az égóáldozatot vagy a you-vágószertartást valahol máshol, talán a főváros környékén végezték el. Az elsô ránézésre argumentum ex silentio típusúnak túnő érv mellett szólnak olyan jósfeliratok, amelyek explicit módon állítják, hogy a Hegynek szánt áldozatot a fővárosban vagy annak környékén mutatták be.

„Hegynek szóló áldozatot mutatunk be Nandannál [a Shang fo"város déli része], hegynek szóló áldozatot mutatunk be [a fóvárostól délre lévő] Hármas Városkapunál, és hegynek szóló áldozatot mutatunk be Chunál [a fóváros külvárosánál].”岳于 南單, 岳于三門, 岳于楚。 ${ }^{30}$ [Heji 34220]

„Yimao napon jóslásszertartás: Nandannál [a Shang főváros déli részénél] álló szertartást mutassunk be a Hegynek esőért.”已卯 卜, 于南单位岳雨。[Tunnan 4362]

„Yimao napon jóslásszertartás: Vonuljunk ki a Hegyhez / mutassuk be a Hegynek a qu-szertartást esóért. Renwu napon jóslásszertartás: a következő tíz nap alatt mutassunk be áldozatot a Hegynek négyszer. A Hegynek a Hármas Kapunál ${ }^{31}$ mutassunk be áldozatot.”已卯卜, 取岳雨。壬午卜, 岳来于旬, 肆。岳于三户。[Heji 32833]

30 Lian 2011: 14.

31 A Sanhu 三户 azonos lehetett a Sanmennel 三門, lásd Lian 2011: 15. 
„Jiashen napon jóslásszertartás: a Földoltárnál áldozzunk különleges szarvasmarhát, [a fővárostól délre lévő] Hármas Városkapunál vonuljunk ki a Hegyhez / mutassuk be a Hegynek a $q u$-szertartást, négyszer.”甲申卜, 于社牢。取岳于三門, 肆。[Heji 34219]

Az utolsó példánál az első verzió esetében egy ellentmondást találunk: amennyiben a qu yue 取岳 valóban a Hegyhez való kivonulást jelenti, ahogy ezt Lian Shaoming véli, úgy a Hármaskapu legfeljebb azt a helyet jelölhetné, amelyen keresztül a szertartást végző́k kivonultak a Hegyhez. Mivel a Hármaskapu délre volt a fóvárostól, így ebben az esetben a Hegyet is ott lenne érdemes keresni. Ugyanakkor, mivel a jóslócsontokra nem jellemző, hogy magyarázó jellegú kiegészítéseket nyújtanának, így sokkal valószínúbbnek tűnik az a feltételezés, hogy a qu yue mégsem a Hegyhez történő kivonulást jelöli, hanem egy speciális, valószínúleg esőkérésre irányuló szertartást. ${ }^{32}$ Valamilyen típusú kivonulási szertartás tehát létezett, de konkrétan a qu yue valószínúleg mégsem erre vonatkozik, tehát az összes fenti, qu yuét tartalmazó mondatban alighanem a második értelmezést kell előnyben részesíteni.

Érdemes kiemelni, hogy az első példában nem a korábban szokásos szerkezet szerepel (ige + 于岳), hanem az egyébként főnévi használatú yue 岳 (Hegy) jelenik meg igeként. Habár elvileg nem zárhatjuk ki, hogy igaza van Ding Shannak 丁山, aki szerint a yue egy áldozattípus, amelyet bármelyik hegynek be lehetett mutatni, ${ }^{33}$ ugyanakkor éppen a korábban idézett kivonulási szertartások arra utalhatnak, hogy inkább konkrét hegyről (esetleg hegyekról) volt szó, ${ }^{34}$ ahogy a Folyónak bemutatott áldozatok is egyértelmúen a Sárga-folyónak szóltak.

Itō 1996: 14.

33 Ding Shan véleményét idézi Kleemann 1994: 226.

34 Kleemann 1994: 226. 
2.2.2. A Hegy befolyási köre

A Heggyel kapcsolatos feliratok döntő többsége az esőkéréshez kapcsolódik, és ez fordítva is igaz, tehát a Sárga-folyó mellett az esőkérő ceremóniák leggyakoribb címzettje a Hegy. ${ }^{35}$

„Égessünk áldozatot a Hegynek, hogy ezáltal legyen esô.”36 尞 岳使又(=有)雨。[Nanming 44]

„Ha a Hegyet kérleljük a jó aratásért, lesz ebből eső?” 于岳求 年, 此雨。[Nanming 424]

„Ha a Hegyet kérleljük a jó aratásért, ebből nagy eső lesz.” 求 年于岳, 兹有大雨。[Nanming 426]

„Jóslásszertartás guiyou napon: ha elzarándokolunk a Hegyhez, esni fog?”癸西卜, 其取岳, 雨。[Cuibian 28]

„Ha elzarándokolunk a Hegyhez, esni fog?” 取岳, 雨。 [Cuibian 29]

„Ha táncot mutatunk be a Hegynek, lesz eső.” ${ }^{37}$ 舞岳又(= 有) 雨。[Heji 14207]

„Jóslásszertartás guiyou napon: vonuljunk a Hegyhez (áldozatra), hogy essen az eső?’38 癸西卜, 其取岳, 雨。[Cuibian 28]

\footnotetext{
Kleemann 1994: 226.

36 Takashima 2006: 25.

37 Serruys 1974: 28.

38 Serruys 1974: 54-55.
} 
„Jóslásszertartás bingwu napon: a Hegy az, aki ártalmára van az esőnek [amitől nem esik]? Vagy a Folyó az, aki ártalmára van az esőnek? Vagy $\mathrm{Nao}^{39}$ az, aki ártalmára van az esőnek?" 丙午卜，唯岳害雨。唯河害雨。唯貽害雨。[Tunnan 2438, Yingguo 2444]

„Gengwu napon jóslás: a Folyó van ártalmára a felhőknek, vagy a Hegy van ártalmára a felhőknek, vagy a Legmagasabb Ốs van ártalmára a felhőknek?”庚午, 貞河害云。唯岳害云。唯高 祖害云。[Tunnan 2105]

A Sárga-folyó (a feliratokon csak egyszerúen Folyó) után a Hegyhez fordultak másodszor leggyakrabban a jó termésért. ${ }^{40}$ Amint a második és harmadik példából is látszik, ez utóbbi természetesen szintén szoros kapcsolatban állt az esővel. A jóslócsontok a Hegycsúccsal kapcsolatban elsősorban annak negatív hatását kívánják kifürkészni, vagyis azt kívánták megtudni, hogy melyik erő lehet ártalmára a termésnek (Itō szóhasználatában: „átkozza meg” a termést). ${ }^{41}$ A Hegyrôl a termésre vonatkozóan általában nem feltételeztek pozitív hatást, csak azt kívántak, hogy az negatívan ne befolyásolja a jó termést.

„A Hegy nincs ártalmára a termésnek? Talán árt a termésnek?”42 岳弗害禾 / 其害禾 [Heji 32229]

„Yiyou napon jóslásszertartás: a Hegy nincs ártalmára a termésnek? Vagy talán árt a termésnek? Bingxu napon (jósoltak): Ártalmára van.”33 乙西卜, 岳弗害禾, 其害禾。丙戌, 其 害。[Heji 32229]

\footnotetext{
Naóról lásd Itō 1996: 61-62.

40 Kleemann 1994: 226.

41 Itō 1996: 16.

42 Keightley 2000: 14.

43 Keightley 2000: 14, vö. Serruys 1974: 64.
} 
„Dingwei napon jósoltak: (jó) termést kérünk a Hegytől, égőáldozatként három kisebb különleges szarvasmarhát ajánlunk fel, és három szarvasmarhát vágunk fel.”丁未, 貞：求禾于岳, 燎三小牢，卯三牛。[Heji 33296, hasonló Heji 33292]

„Jóslásszertartás xinhai napon: Talán a Hegy van ártalmunkra? Áldozzunk ${ }^{44}$ a Hegynek? Jóslásszertartás xinhai napon: a Hegy nincs ártalmára a gabonának [termésnek]? Nem kell áldozni a Hegynek ${ }^{45}$ Jóslásszertartás jiashen napon: a Hegy nincs ártalmára a gabonának? Vagy esetleg ártalmára van a gabonának?” 辛亥卜, 岳其害, 又[=侑]岳。辛亥卜, 岳弗害禾, 弜又 岳。甲申卜, 岳弗害禾。其害禾。 ${ }^{46}$ [Heji 34229]

Itō Michiharu 伊藤道治 a Sárga-folyó és az eső közötti kapcsolatot a víz jellegben látja, ugyanakkor nyitva hagyja az esô és a Hegy közötti fogalmi kapcsolat okát. ${ }^{47}$ Ezzel kapcsolatban érdemes megjegyezni, hogy az eredetileg 'Hegycsúcs' jelentéssel bíró yue valószínúleg a csúcs körül gyülekező felhők miatt asszociálódhatott az esővel, és ennek következtében a terméssel.

\section{Összefoglalás}

A fentiekben megpróbáltam összegyújteni azokat a Shang-kori jóslócsontokon fennmaradt feliratokat, amelyek a Hegynek vagy Hegycsúcsnak (yue 岳) nevezett, általában a Songshannal 峪山 azonosított hellyel, illetve annak szellemével kapcsolatos rítusokról tudósítanak. A jóslócsontok vizsgálatából megállapítható, hogy a Heggyel összefüggésben az állatáldozatok voltak a legjellemzőbb szertartások, ezek különböző típusai közül pedig kiemelendő az égő́ldozat (liao 燎) és az ún. you-vágóáldozat (酊). Számos utalás található arra is, hogy létezett egy

44 A you 又 legalább kilenc különböző Shang-kori jelentéséről lásd Takashima 1996: 246-247, 251-253, 261-277, 303-348.

45 A rész értelmezéséről lásd Gong 2010: 166.

46 Lian 2011: 12.

47 Itō 1996: 20-21. 
szertartás, amelynek központi cselekménye a Hegyhez történő kivonulás volt, még ha nem is minden, látszólag erre utaló kifejezés fedte valójában ezt a rituális cselekményt (Lian Shaoming állítása ellenére a qu yue 取岳 kifejezés például valószínúleg nem). Ezeken kívül néhány utalást találunk a Heggyel kapcsolatos egyéb vallási jelenségekre: imádkozás (dao 禱) vagy kérlelés (qiu 求), a si-rítus 祀, illetve a (rituális) tánc bemutatása (wu 舞). Ami a szertartások időpontját illeti, azokat döntő többségben a tíz égi törzs xin 幸 napján mutatták be, ami tehát az ősöknek bemutatott áldozatokhoz hasonlóan a természeti erők esetében is egy kidolgozott rituális naptárra utal. A szertartások helyszínével kapcsolatban az valószínúsíthető, hogy ezeket meghatározó módon nem magánál a Hegynél, hanem a Shang főváros közelében, annak külvárosi részében tarthatták, így a szertartások a Hegynek szóltak, de nem a Hegynél zajlottak. A rítusok meghatározó többségének egyértelmú célja a megfelelő mennyiségú eső, illetve ezzel összefüggésben a jó termés volt.

\section{Elsődleges források}

[Cuibian =] Yinqi cuibian 殷契粹編 [Válogatott Shang-kori feliratok].

Szerk. Guo Moruo 郭沫若 [rev.] Beijing: Kexue Chubanshe, 1965.

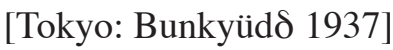

[Heji =] Jiaguwen heji 甲骨文合集 [Jóslócsontok teljes gyújteménye]. 13 kötet. Szerk. Guo Moruo 郭沫若 - Hu Houxuan 胡厚宣. Beijing: Zhonghua Shuju, 1978-82.

[Heji shiwen =] Jiaguwen heji shiwen 甲骨文合集文 [Jóslócsontok teljes gyújteménye]. Főszerk. Hu Houxuan 胡厚宣. Beiijing: Zhongguo Shehui Kexue Chubanshe, 1999.

[Nanming 南明 $=]$ Hu Houxuan 胡厚宣. Ming Yishi jiu cang jiagu wenzi 明 義士舊藏甲骨文字 [J. M. Menzies régi jóslócsont-feliratainak gyújteménye]. Beijing: Laixunge Shudian, 1951. 
[Tunnan =] Xiaotun nandi jiagu 小屯南地甲骨 [Jóslócsontok Xiaotun déli részéról]. Összeállította: Zhongguo Shehui Kexueyuan Kaogu yanjiusuo 中國社會科學院考古研究所. 2 kötet. Beijing: Zhonghua Shuju. 1980, 1983.

[Yingguo $=$ ] Li Xueqin 李學勁, Qi Wenxin 齊文心, Ai Lan 艾蘭 (Sarah Allan) (eds.) Yingguo suocang jiaguji 英國所藏甲骨集 (Oracle Bone Collections in Great Britain). Összeállította: Zhongguo Shehui Kexueyuan Lishi yanjiusuo 中國社會科學院歷史研究所 and School of Oriental and African Studies, University of London. Beijing: Zhonghua Shuju, 1985.

\section{Hivatkozott szakirodalom}

Eno, Robert 2009. „Shang State Religion and the Pantheon of the Oracle Text.” In: John Lagerwey and Marc Kalinowski (eds.) Early Chinese Religion. Part One: Shang through Han (1250 BC-220 AD). LeidenBoston: Brill, 41-102.

Gong Bo 龚波 2010. „Cong jiasheju de fouding xingshi kan jiaguwen zhong de $w u, b i$ yu $b u, f u$ zhi bie 从假设句的否定形式看甲骨文中的勿、 弜与不、弗之别 [A jóslócsontokon szereplő wu/bi és bu/fu megkülönböztetése a feltételes mondatok tagadó szerkezete alapján]." Zhongguo yuwen 中国语文 335: 163-167.

Itō, Michiharu 1996. „Religion and Society.” In: M. Itō - K. Takashima Studies in Early Chinese Civilization. Vol. 1. Text. [Ed. Gary F. Arbuckle] Osaka: Kansai Gaidai University Press, 1-178.

Keightley, David N. 1978. Sources of Shang History. Berkeley and Los Angeles: University of California $P$ ress.

Keightley, David N. 1982. „Review of Akatsuka Kiyoshi: The Culture of Early China: A Study in Historical Method." Harvard Journal of Asiatic Studies 42.1: 267-320. 
Keightley, David N. 1990. „Sources of Shang History: Two Major Oracle-Bone Collections Published in the People's Republic of China." Journal of the American Oriental Society 110.1: 39-59.

Keightley, David N. 1997. „Graphs, Words, and Meanings: Three Reference Works for Shang Oracle-Bone Studies, with an Excursus on the Religious Role of the Day or Sun." Journal of the American Oriental Society 117.3: 507-524.

Keightley, David N. 2000. The Ancestral Landscape: Time, Space, and Community in Late Shang China, ca. 1200-1045 B.C. Berkeley: University of California.

Keightley, David N. 2014. These Bones Shall Rise Again: Selected Writings on Early China. (Ed. by Henry Rosemont Jr.) Albany, NY: SUNY Press.

Kleeman, Terry F. 2004. „Mountain Deities in China: The Domestication of the Mountain God and the Subjugation of the Margins." Journal of the American Oriental Society 114.2: 226-238.

Kósa Gábor 2012. „A Shang-kori szakrális naptárrendszer.” Axis (Vallástörténeti folyóirat) I.2: 4-13.

Li Guoqiang 2007. „Sacrifices et domestication des bovins dans la Chine antique sous les Shang postérieurs (vers 1300 à 1046 avant J.-C.)." Anthropozoologica 42.1: 19-46.

Lian Shaoming 连劭名 2011. „Shangdai wangji zhong de he yu yue 商代望 祭中的河与岳 [A Folyó és a Hegy szerepe a Shang-kori áldozatbemutatásokban].”Yindu xuekan 殷都学刊 2011.1: 12-16.

Serruys, Paul L. M. 1974. „Studies in the Language of the Shang Oracle Inscriptions." T'oung Pao (2nd series) 60.1-3: 12-120.

Takashima, Ken-ichi 1996. „Language and Palaeography.” In: M. Itō - K. Takashima Studies in Early Chinese Civilization. Vol. 1. Text. [Ed. Gary F. Arbuckle] Osaka: Kansai Gaidai University Press, 179-505. 
Takashima, Ken-ichi 2000. „Towards a More Rigorous Methodology of Deciphering Oracle-Bone Inscriptions." T'oung Pao (2nd series) 86.4/5: 363-399.

Takashima, Ken-ichi 2002. „Some Ritual Verbs in Shang Texts.” Journal of Chinese Linguistics 中國語言學報 30.1: 97-141.

Takashima, Ken-ichi 2006. „Some Linguistic Aspects of the Shang and Early Western Zhou Bronze Inscriptions." In: Christoph Anderl and Halvor Eifring (eds.) Studies in Chinese Language and Culture: Festschrift in Honour of the 60th Birthday Christoph Harbsmeier. Oslo: Hermes Academic Publishing and Bookshop, 13-30.

Takashima, Ken-ichi 2009. „Jìsì 祭祀: A Reconstruction of the Jì Sacrifice and the Sì Ritual in Ancient China." In: Xiaobing Wang-Riese and Thomas O. Höllmann (eds.) Time and Ritual in Early China. Wiesbaden: Otto Harrassowitz, 33-68.

Wilkinson, Endymion 2013. Chinese History: a New Manual. Cambridge, Mass. / London: Harvard University Asia Centre. 